\title{
EKOLITERASI MASYARAKAT STREN KALI KELURAHAN KARANGPILANG KOTA SURABAYA MENUJU NEW REALITY ERA PANDEMI COVID-19
}

\author{
Pheni Cahya Kartika ${ }^{1}$, Ruspeni Daesusi ${ }^{2}$, Himatul Farichah ${ }^{3}$ \\ ${ }^{1)}$ Program Studi Pendidikan Bahasa dan Sastra Indonesia, Fakultas Keguruan dan Ilmu Pendidikan, \\ Universitas Muhammadiyah Surabaya \\ ${ }^{2)}$ Program Studi Pendidikan Biologi, Fakultas Keguruan dan Ilmu Pendidikan, Universitas Muhammadiyah \\ Surabaya \\ ${ }^{3)}$ Program Studi Teknik Sipil, Fakultas Teknik, Universitas Muhammadiyah Surabaya \\ e-mail: phenicahya.sulistiyo@gmail.com
}

\begin{abstract}
Abstrak
Area pemukiman padat penduduk yang berada di tepian sungai atau disebut area stren kali memiliki permasalahan yang komplek yakni, permasalahan sosial, pendidikan, ekonomi dan juga kesehatan lingkungan, terlebih dimasa pandemi Covid-19 ini. Di masa pandemi Covid 19 ini, penduduk di kawasan padat penduduk yang berada pada lingkungan yang dekat dengan sungai yang cukup deras harus lebih berhati-hati. Sebagaimana diketahui bahwa peningkatan kasus Covid di Kota Surabaya sudah menunjukkan angka yang cukup tinggi. Sehingga Surabaya ditetapkan sebagai zona merah. Petugas Satgas Covid-19 yang sudah dibentuk oleh pimpinan setempat masih berupaya mengawasi keadaan di wilayah tersebut terutama RW.01 yakni daerah stren kali pada RT 2 dan RT.6. Permasalahan mencakup kurang pengetahuan dasar dalam penanganan keadaan pandemi Covid-19 dan menyikapi kehidupan pada new reality saat era pandemi. Dengan metode 3 (tiga) bidang ecoliterasi yakni eco-healthy, eco-collaboration dan eco-education, metode tersebut diharapkan dapat menyelesaikan masalah terutama pada masyarakat di daerah stren kali pada RT. 2 dan RT 06. Waktu kegiatan dilaksanakan dengan standar protokoler kesehatan yakni skala kecil dan daring jika melibatkan banyak warga.
\end{abstract}

Kata Kunci: Ekoliterasi, Karangpilang, Stren Kali, Pandemi Covid-19

\begin{abstract}
Densely populated residential areas located on the river banks which are called the stren of river have complex problems including social, educational, economic, and environmental health problems, in particular during the Covid-19 pandemic. During the Covid-19 Pandemic, residents in densely populated areas close to a quite swift river have to more careful. As it is known that in Surabaya, the rising number of Covid-19 cases is among a high number. Therefore, Surabaya is designed as a red zone. The Covid-19 task force that has been formed by the local government is still trying to oversee the situation in that area, especially RW.01, namely the stren of river in RT 2 and RT. 6. The problems are including the lack of basic knowledge about handling a covid-19 pandemic and responding to life in new reality during the pandemic era. By using three 3 approaches of ecoliteration, namely eco-healthy, eco-collaboration and eco-education, these methods are expected to solve problems, particularly for residents in sren of river in RT. 2 and RT 06. The activity time is performed with standard health protocols, which are by organizing the activity in small scale and by helding online activity if it involves many residents.
\end{abstract}

Keywords: Ecoliteration, Karangpilang, Stren Kali, Pandemic Covid19

\section{PENDAHULUAN}

Pendahuluan menguraikan latar belakang permasalahan yang diselesaikan, isu-isu yang terkait dengan masalah yg diselesaikan, kajian tentang penelitan dan atau kegiatan pengabdian pada masyarakat yang pernah dilakukan sebelumnya oleh pengabdi lain atau pengabdi sendiri yang relevan dengan tema kegiatan pengabdian yang dilakukan. Di pendahuluan harus ada kutipan dari hasil penelitian/pengabdian lain yang menguatkan pentingnya PKM. 
Pendidikan berbasis literasi sangat gencar dalam mengkampanyekan adanya suatu perubahan dalam semua sektor dan sub bidang ilmu. Beragam cara dan upaya dilaksanakan, salah satu bentuk literasi dalam menjaga ekologi lingkungan yakni disebut gerakan literasi ekoliterasi. Ekoliterasi sendiri lahir berdasarkan akan keberadaan orang yang melek lingkungan (Soemarwoto, 1994). Ekoliterasi (eco-literacy) atau melek ekologi, pertama kali dikemukakan oleh Fritjof Capra dalam bukunya berjudul The Web of Life: A New Understanding of Living Systems (Capra, 1997). Istilah ekoliterasi atau melek ekologi, menurut Capra (2007) adalah tercapainya tingkat pemahaman yang tinggi tentang pentingnya prinsip ekosistem dan menggunakan prinsip tersebut untuk membentuk masyarakat yang berkelanjutan.

Sebagai salah satu kota besar di Indonesia yang menjadi pusat perekonomian di Jawa Timur, mengakibatkan tingginya tingkat urbanisasi yang terjadi di Surabaya. Bagi kamu urban yang memiliki penghasilan rendah, keterbatasan akses untuk mendapatkan hunian yang layak menjadi permasalahan tersendiri. Hal tersebut dapat memberikan ruang gerak untuk menyusup ke pinggiran kota yang masih murah, termasuk dalam ruang-ruang publik seperti kolong jalan tol, pinggiran rel dan tepian sungai (Setiawan, 2010). Mereka mendirikan hunian-hunian permanen maupun non permanen sebagai bentuk okupasi atas lahan di tepian sungai atau yang sering disebut stren kali atau bantaran sungai (Rahmadi, 2009).

Wilayah stren kali di Kota Surabaya sangat luas dan menyebar di beberapa titik. Perkembangan hunian di wilayah stren kali ini sudah berlangsung sejak lama. Salah satu wilayah stren kali berada di daerah Kecamatan Karangpilang. Sebagai kecamatan yang berbatasan langsung dengan 2 kota yakni kecamatan Sepanjang Sidoarjo dengan Driyorejo Gresik, kawasan stren kali Karangpilang ini mulai padat pemukiman semenjak era 1980an (Soenyono, 2006). Pada studi ini, Kelompok masyarakat yang merupakan mitra adalah RW.01 Kelurahan Karangpilang Kota Surabaya. RW 01 memiliki 7 RT. Lokasi tersebut berada di sepanjang tepian sungai anak Brantas yang cukup besar dan memiliki pengaruh utama, sebab perbatasan langsung sisi timur dan pada sisi barat jalan utama jalur Surabaya Gresik dan Sidoarjo. Wilayah stren kali ini merupakan area pemukiman padat penduduk yang memiliki permasalahan yang komplek.

Berdasarkan survei, ditemukan permasalahan yang terjadi pada area stren kali yakni kurangnya pemahaman kebersihan sungai, rendahnya kepedulian warga terhadap keadaan pemukiman yang rawan bencana, terlebih di era pandemi covid-19 ini. Pemerintah setempat kurang mendukung keberadaan daerah stren kali yang seharusnya tidak disepelekan, termasuk masalah ekonomi dan pendidikan. Banyak hal yang bisa diupayakan demi keberlangsungan dan keseimbangan lingkungan wilayah sungai dengan pemukiman di sekitarnya. Upaya tersebut salah satunya dengan cara mengarahkan masyarakat dalam melaksanakan memberdayakan kegiatan yang berhubungan dengan keseharian yakni literasi lingkungan atau yang biasanya disebut ekoliterasi, sebagai upaya memperbaiki kualitas wilayah stren kali RW. 01 Karangpilang.

Pada awalnya kegiatan yang difokuskan di wilayah stren kali Karangpilang ini adalah mengupayakan peningkatan belajar terhadap anak dan remaja sehingga mitra membentuk kampung belajar. Namun seiring perkembangan dan menimbang potensi keberadaanya, pada akhirnya kegiatan menyentuh bidang lainnya yang berkaitan dengan nilai kebaikan terutama pendidikan, kesehatan, dan sosial budaya. Di wilayah stren kali terdapat program Jogo Kali yang diusulkan oleh warga RW 01 Kelurahan Karang Pilang, Kecamatan Karang Pilang. Program Ayo Jogo Kali adalah program warga RW 01 menciptakan tata tertib untuk menjaga ekosistem dan habitat sungai yang akhirnya berdampak positif bagi manusia yang hidup disekitarnya. Dengan cara menumbuhkan kesadaran warga mengenai pentingnya hidup bersih dan sehat meskipun berada di bantaran sungai.

Cara warga menerapkan program Ayo Jogo Kali adalah membuat septictank di setiap rumah untuk meminimalisir pencemaran sungai lewat kotoran manusia, atau limbah rumah tangga, dan memperbanyak tong sampah untuk meminimalisir warga yang membuang sampah sembarangan khususnya buang sampah di bantaran sungai. Program ini mulai diterapkan oleh warga khususnya warga RW01 Kelurahan Karang Pilang, Kecamatan Karang Pilang sejak tahun 2016 hingga sekarang. Hasilnya memang terlihat nyata bahwa kini lokasi tersebut bersih, indah dan juga rapi dibandingkan sebelumnya.

Dilihat dari peta wilayah RW 01 berada tepat di tepian sungai Brantas dan berbatasan langsung dengan kecamatan Sepanjang Sidoarjo, sehingga dikategorikan wilayah berbatasan 
dengan dilewati sungai yang cukup deras arusnya. Upaya revitalisasi secara fisik sudah dilaksanakan setahun yang lalu, dalam jangka watku relatif lama kurang lebih 5 bulan lamanya. Adapun permasalahan salah satunya tingkat kesadaran warga sendiri dalam upaya perbaikan, sehingga langkah pendekatan dan pemberian stimulus dianggap sebagai upaya efektif demi terwujudnya kegiatan tersebut walaupun cukup lama dan perlahan. Area sungai terlihat cukup luas dan rawan bencana seperti penuturan beberapa RT dan warga. Selain sampah tanaman eceng gondok juga menjadi faktor terjadinya rawan bencana banjir dan merusak ekosistem hewan seperti ikan. Upaya pembersihan dilakukan secara suka rela dan gotong royong. Area rumah penduduk yang beragam membuat kesulitan sendiri dalam membersihkan, mulai dari adanya tumpukan sisa bangunan, aliran got yang mampet di sekitar warga sehingga menjadi kendala baru, sampah rumah tangga, dan keadaan bangunan rumah yang dekat sekali dengan sungai. (1) Upaya warga selain pembersihan fisik juga mengembangkan secara fisik dan perlahan satu demi satu, (2) Mengumpulkan warga dan membekalinya untuk terjun dalam kegiatan revitalisasi stren kali, sampai pada pembentukan gerakan "ayo jogo kali", (3) Pembangunan jalan (memberi space) untuk jalan sebesar kurang lebih 4 meter yang kemudian jalan tersebut dipasang paving agar rapi. (4) menambahkan vegetasi atau tanaman pada area stren kali agar terlihat lebih hijau dan rindang, (5) Pembangunan area umum yang dapat digunakan untuk kegiatan warga stren kali. seperti perpustakaan, area bermain, ruang belajar. (6) Kegiatan inovasi dan produktif yang sudah dilaksanakan, menghias jalan, membuat aksesoris tepian jalan atau rumah rumah dengan desain sederhana dengan mengandalkan kreatifitas warna dan pemenfaatkan warna cat.

Semenjak pemberlakuaan pembatasan sosial berskala besar atau PSPB di kota Surabaya mengindikasi bahwa terjadi lonjakan besar dalam kejadian pandemi yang mulai masuk wilayah jawa timur khususnya Surabaya. Terhitung semenjak bulan Januari sebelum dinyatakan bahwa kota Surabaya memiliki pasien dengan covid 19, walikota Surabaya sudah banyak mempersiapkan beberapa hal untuk mengupayakan warga Surabaya tetap terjaga namun sampai bulan Juli warga yang terinfeksi masih dikategorikan tinggi. Wilayah RW.01 kelirahan Karangpilang yang menjadi sasaran pengabdian juga mengikuti arahan keadaan pandemi, antara lain adanya satgas covid yang ditugaskan di wilayah RW. 01 sejumlah 7 orang satgas yang ditempatkan pada setiap RT, dan wilayah stren kali yakni wilayah RT. 02 dan RT. 06 yang masing masing memiliki 1 satgas dengan tugas terkomando oleh RW, Babinkamtibmas samapi pada tingkat kelurahan dan kecamatan. Tercatat sampai bulan juli korban yang terinfeksi virus di RW. 01 berjumlah sebanyak 7 orang dan 3 orang meninggal, 2 diantaranya diisolasi di Rumah sakit. Dan lainnya isolasi mandiri dengan diawasi oleh satgas covid dan pantauan Puskesmas Karangpilang. Terkait daerah stren kali di wilayah RW. 01 memiliki cara dalam menyikapi keadaan selain mengikuti protocol juga tetap beraktifitas dengan system yang menyesuaikan keadaan seperti anak sekolah yang belajar dirumah, warga yang bekerja di rumah, menggunakan masker saat beraktifitas keluar rumah Namun lambat laun semakin lama masyarakat merasa jenuh sehingga terjadi kebosanan yang menimbulkan penurunan tingkat kedisiplinan dalam menaati protokoler covid-19. Berdasarkan hasil observasi dan diskusi antara tim pengabdian dengan mitra dalam hal ini Pak RW berikut perangkat terkait keadaan terkini pada masa pendemi, maka permasalahan terdiskripsi sebagai berikut;

a) Berkaitan dengan kebersihan dan kesehatan lingkungan wilayah strenkali, kurangnya kesadaran warga dalam menyikapi kebersihan terutama saat pandemic covid-19, Kurang pedulinya warga sebagai penduduk yang berada dalam pemukiman rawan bencana banjir, banyak anak bermain bebas namun belum menggunakan standar protocol kesehatan pandemic covid-19, seperti tidak menggunakan masker, pola cuci tangan dan sebagianya. Kurangnya pemahaman warga bahwa kesehatan terlebih meningkatkan imunitas tubuh dalam menjaga fisik saat pandemi covid-19, pemanfaatan wilayah stren kali.

b) Bidang Ekonomi produktif, Dana yang digunakan untuk revitalisasi belum masimal hanya menggunakan dari dana kas RW.01 dan swadaya masyarakat, banyak warga yang mengalami kesulitan bekerja terutama yang tidak memiliki pekerjaan tetap sehingga menjadi warga dengan ekonomi berdampak, Daerah stren kali terutama pemukiman yang sudah menempati lebih dari 20 tahun berhak atas kelegalitasan/ sertifikasi tanah.

c) Dalam Pendidikan juga memiliki beberapa permasalahan yakni Ide dalam mengembangkan area stren kali terbatas, Kurangnya motivasi warga terutama anak anak dalam upaya perkembangan belajar wilayah sungai, Ketidaksadaran warga dalam upaya 
membentuk lokasi stren kali yang berdampak dalam pendidikan khususnya anak dan remaja (Abidin, 2017).

Berdasarkan gambaran permasalahan mitra tersebut maka prioritas dalam mencari solusi permasalahan mencakup 3 bidang tersebut yang dianggap isidentil yakni

1. Bidang kesehatan, Kurangnya kesadaran warga dalam menyikapi pandemic covid-19 dan kurangnya pemahaman warga bahwa kesehatan terlebih meningkatkan imunitas tubuh dalam menjaga fisik saat pandemi covid-19

2. Bidang ekonomi produktif, banyak warga yang mengalami kesulitan bekerja terutama yang tidak memiliki pekerjaan tetap sehingga menjadi warga dengan ekonomi berdampak sehingga perlunya diberikan pengetahuan dan stimulus dalam mengatasi hal tersebut.

3. Bidang pendidikan, Ide dalam mengembangkan area stren kali terbatas dan kurangnya motivasi warga terutama anak anak dalam upaya perkembangan belajar wilayah sungai.

Permasalahan yang dianggap prioritas tersebut membutuhkan solusi yang tepat, dan diupayakan mengalami peningkatan, maka dalam menentukannya perlunya pola dalam sesuai dengan yang dibutuhkan warga. Maka tim merujuk pada solusi tiga bidang tersebut yang akan terlaksana dengan pendekatan ekoliterasi yakni Eco-Healthy (Literasi bidang kesehatan), EcoCollaborasi (literasi perpaduan ilmu), dan Eco-Education (literasi Pendidikan), secara rinci akan terdeskripsi pada bab metode.

\section{METODE}

Pada kegiatan pemberdayaan ini metode pelaksanaan yang akan digunakan menggunakan 3 (tiga) pendekatan yakni Eco-Healthy (Literasi bidang kesehatan), Eco-Collaborasi (literasi perpaduan ilmu), dan Eco-Education (literasi Pendidikan) sebagaimana terlihat pada Gambar 1.

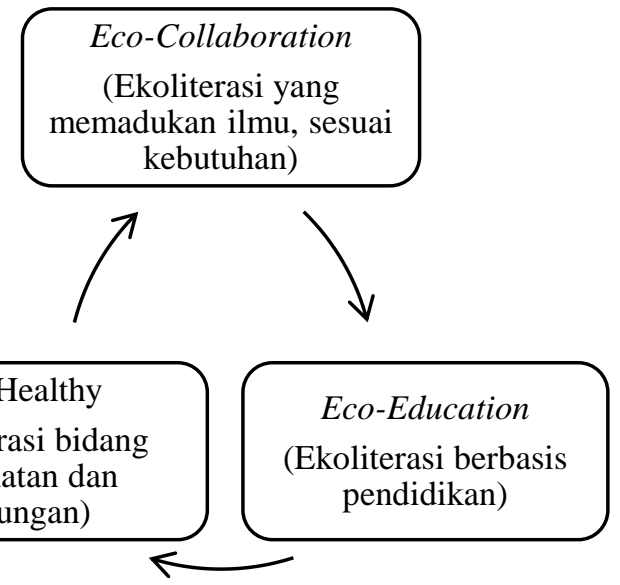

Gambar 13 (Tiga) metode pendekatan sebagai upaya pendekatan

Dengan memanfaatkan beragam kegiatan yang terprogram antara lain yakni

a. Eco-Healthy (Literasi bidang kesehatan), pendekatan yang digunakan sebagai cara dalam mengatasi permasalah kesehatan warga terkait kesehatan masyarakat wilayah daerah strenkali baik saat pandemi covid-19 maupun pasca pandemi covid-19, dengan cara sosialiasai mengenai nilai kesehatan yang penting kemudian berlanjut pada penyuluhan yang dibutuhkan, yakni penyuluhan kesehatan unuk warga wilayah sungai yang banyak memberikan pengetahuan masyarakat mengenai bagaimana menjadaga kesehatan lingkungan baik saat pandemic maupun pasca pandemic.

b. Eco-Collaboration (literasi perpaduan ilmu), merupakan pendekatan yang mengupayakan literasi dalam bidang lain yang dianggap mampu dikolaborasikan dalam peningkatan bidang tertentu bergantung pada kebutuhan masyarakat, dalam hal ini terkait perekonomian warga, pada era pandemi ini salah satunya yakni upaya dalam menyiapkan ketahanan pangan secara mandiri dan memiliki progress dalam perekonomian, maka tim pengabdian memilih urban farming atau pertanian di wilayah kota sebagai salah satu 
kegiatan sekaligus solusi. Urban farming berkonsentrasi dalam pemberdayaan warga secara mandiri dalam membuat lahan pertanian sederhana juga peternakan

c. Eco-Education (literasi Pendidikan), dalam bidang ini akan memanfaatkan solusi praktis dengan tingkat keberlanjutan yakni inisiasi rumah ekoliterasi dengan harapan gerakan literasi berbasis ekologi lingungan wilayah strenkali akan tetap berjalan dan mewarisi generasi ke depan dalam menjaga keseimbangan pemukiman wilayah tersebut, bahkan semakin berkembang sesuai eranya (Aminuddin, 2013).

Dari ketiga metode tersebut adapun upaya pelaksanaaan program pengabdian diilustrasikan sesuai dengan Gambar 2.

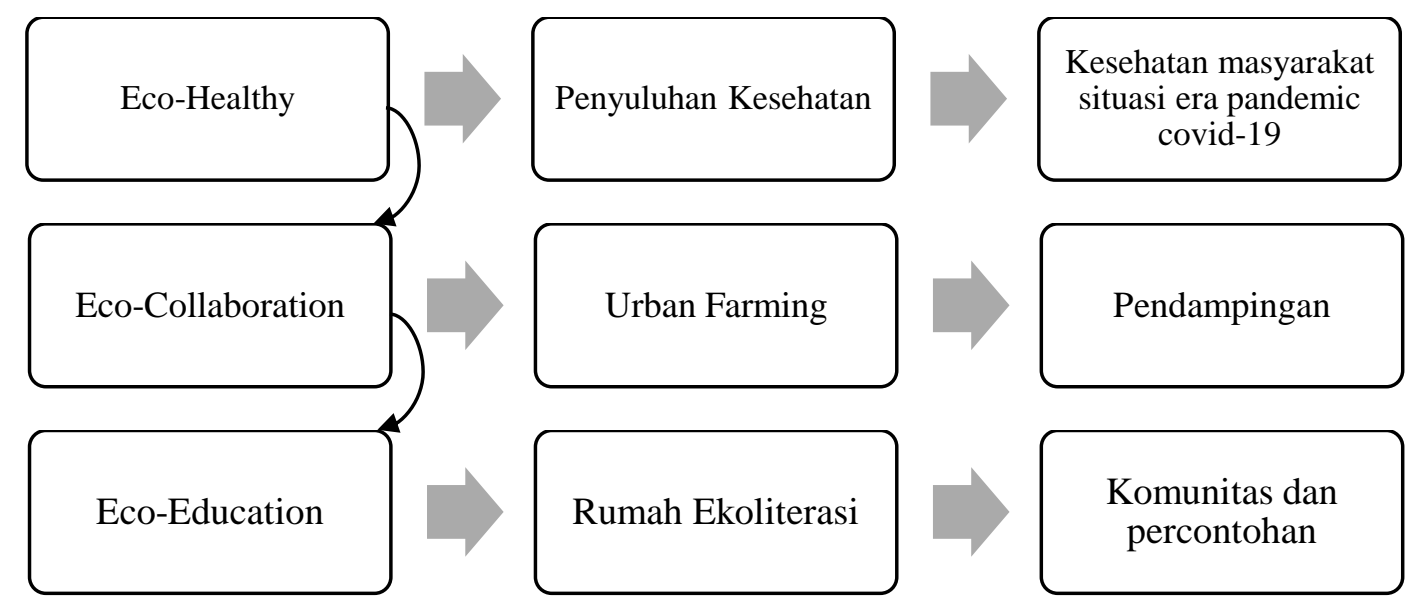

Gambar 2. Tiga program ekoliterasi yang akan dilaksanakan sebagai bentuk solusi dan luaran keseluruhan permasalahan.

Pelaksanaan literasi terdiri dari beberapa tahap kegiatan, mulai sosialisasi program dan tujuan kegiatan, penyuluhan program yang mendukung kegiatan literasi yakni sosialisasi ekoliterasi secara daring, kegiatan penyuluhan urban farming secara luring dan daring, hingga pembentukan komunitas.

Sosialisasi ekoliterasi dilaksanakan saat pandemi sehingga diberlakukan standar protokol, melibatkan pengurus kampung (Ketua RW) dan kelompok kecil warga, dan dilanjutkan sosialisasi daring kepada beberapa warga.

Kegiatan urban farming diantaranya adalah penanaman sayur sebagai ketahanan pangan dan tanaman serai, dilanjutkan dengan hidroponik, dan budidaya lele dalam ember (budidamber). Pada kegiatan urban farming sebelumnya diadakan penyuluhan kepada warga secara tatap muka langsung, kemudian dilanjutkan penyuluhan secara daring, dimana kali ini pesertanya lebih banyak. Budidaya ikan dalam ember dan hidroponik dilokasikan di lahan di depan pos RT, dimana rencananya di lokasi tersebut akan diadakan rumah percontohan ekoliterasi.

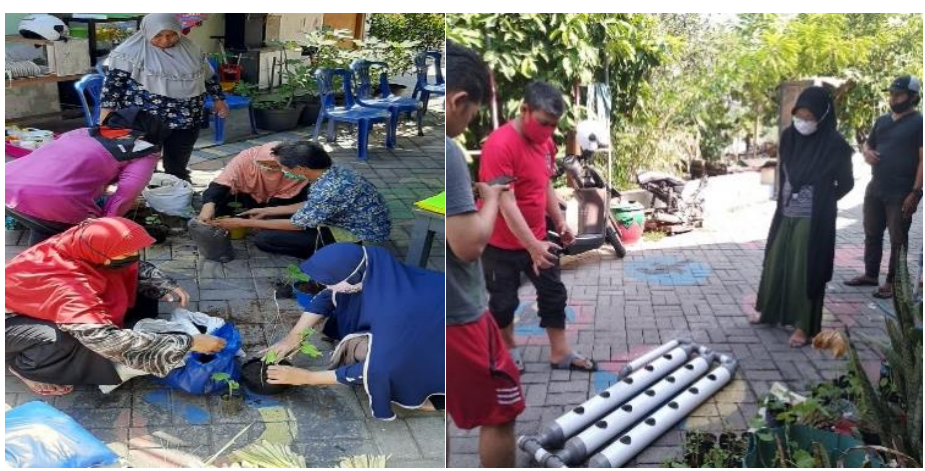

Gambar 3. Kegiatan penanaman sayur pd pot dan persiapan hidroponik Sumber: dokumen pribadi, hasil kegiatan

Penanaman sayur media hidropinik dari semai hingga mendekati panen kisaran waktu 38 sampai 42 hari (Gambar 4) 


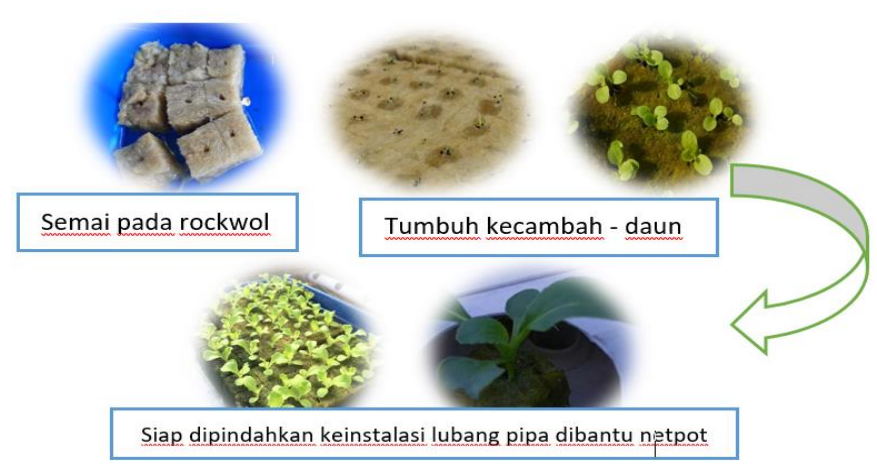

Gambar 4. Penanaman sayur media hidroponik dari semai hingga mendekati panen Sumber: dokumen pribadi, hasil kegiatan

Setelah pada tahapan kegiatan urban farming juga adanya kegiatan penyuluhan daring yakni penyuluhan kesehatan, sosialisasi mitigasi bencana dan pelatihan literasi

\section{HASIL DAN PEMBAHASAN}

Pada pembahasan kali ini akan menguraikan berdasarkan hasil kegiatan yang telah dilaksankaan yakni pada tahapan kegiatan sosialisasi yang dilakukan secara daring

a. Eco-Healthy yakni kegiatan penyuluhan kesehatan lingkungan bagi warga (Gambar 5). Kegiatan ini diharapkan menjadi bekal pengetahuan dan pemahaman yang lebih baik mengenai kesehatan lingkungan. Penyuluhan kesehatan lingkungan dilaksanakan secara daring dari pakar kesehatan dengan basic kedokteran, yakni dosen pada Fakultas Kedokteran Universitas Muhammadiyah Surabaya. Narasumber memberikan arahan dan rambu dalam menangani permasalahan kesehatan lingkungan, dengan menyertakan media informasi video, hasilnya menginspirasi warga dalam kegiatan literasi, saat penyuluhan luring juga memberikan praktik tentang pencegahan dan cara sikapi ditengah pandemic.

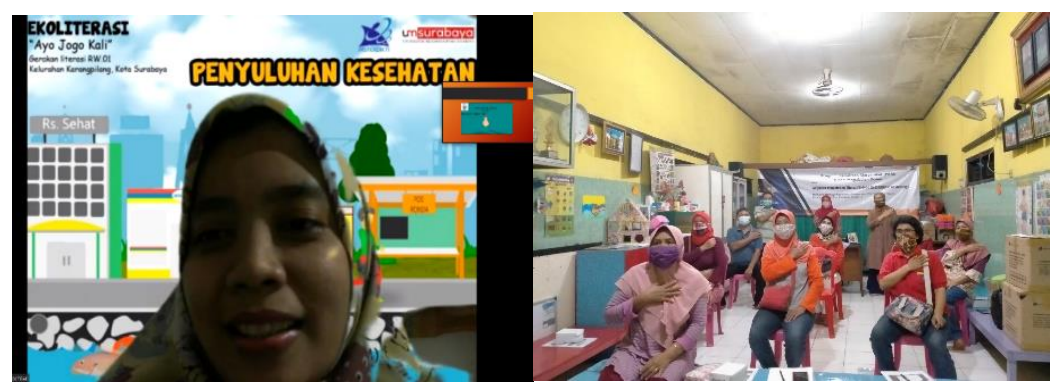

Gambar 5. Foto kegiatan penyuluhan kesehatan lingkungan kepada warga Sumber: dokumen pribadi, hasil kegiatan

b. Eco-Collaboration, merujuk pada dua kegiatan yaitu program urban farming berupa pertanian dan perikanan lahan kota dengan tujuan untuk pertahanan pangan warga secara mandiri dan sederhana (Gambar 6. (a)). Kegiatan urban farming dilaksanakan pada bulan Juni, dimulai dengan survei/kunjungan ke agrowisata mini milik Dinas Pertanian Kota Surabaya. Selanjutnya warga mulai menanam bibit sayur (tomat, terong, kemangi, labu botol, dan pare), dan tanaman obat seperti serai, dan bunga rosela. Program kedua berhubungan dengan sigap tanggap bencana dengan mengadakan sosialisasi mitigasi bencana kepada warga, baik secara daring maupun luring (Gambar 6. (b)). 

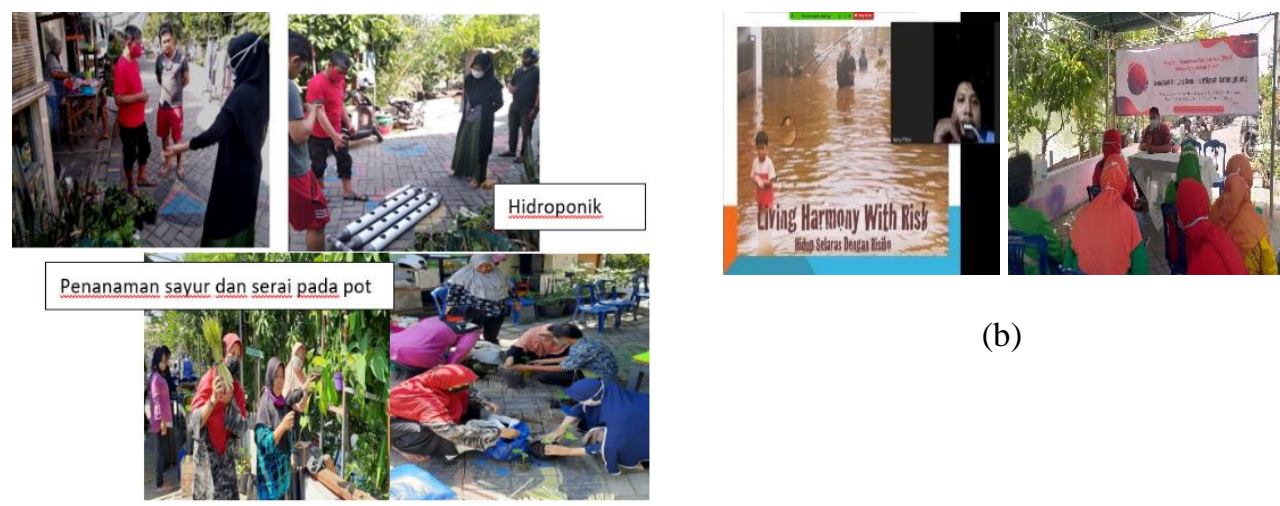

(b)

(a)

Gambar 6. Foto kegiatan (a) urban farming dan (b) penyuluhan mitigasi bencana

Sumber: dokumen pribadi, hasil kegiatan

Tabel 1. Kegiatan kegiatan Ekoliterasi pendekatan eco-collaboration

\begin{tabular}{cccc}
\hline Kegiatan Ekoliterasi & mitra & luaran & sifat \\
\cline { 2 - 4 } penyuluhan hidroponik & kader & Mulai semai biji selada sayur & $\begin{array}{c}\text { Langsung } \\
\text { kelompok kecil }\end{array}$ \\
\hline Pelatihan budibamber & $\begin{array}{c}\text { Kader, } \\
\text { katar }\end{array}$ & $\begin{array}{c}\text { Sudah ada 3 ember percontohan dan 150 } \\
\text { benih ikan lele }\end{array}$ & $\begin{array}{c}\text { Langsung } \\
\text { kelompok kecil }\end{array}$ \\
\hline $\begin{array}{c}\text { Penanaman sayur dan bunga } \\
\text { pot pot setiap rumah }\end{array}$ & $\begin{array}{c}\text { Semua } \\
\text { warga }\end{array}$ & $\begin{array}{c}\text { Tanam pohon 100 pohon serai, rosela, } \\
\text { cabai, labu botol, dan lainnya }\end{array}$ & $\begin{array}{c}\text { Langsung } \\
\text { kelompok kecil }\end{array}$ \\
\hline Penyuluhan daring & $\begin{array}{c}\text { Semua } \\
\text { warga }\end{array}$ & Pemahaman materi ekoliterasi & $\begin{array}{c}\text { Daring } \\
\text { Sebanyak 25 } \\
\text { warga }\end{array}$ \\
\hline $\begin{array}{c}\text { Sosialisasi mitigasi bencana } \\
\text { (penyuluhan langsung) }\end{array}$ & Kader & Pemahaman kiat tangguh bencana wilayah \\
strenkali & $\begin{array}{c}\text { Langsung } \\
\text { kelompok kecil }\end{array}$ \\
\hline
\end{tabular}

Sumber : hasil kegiatan langsung selama kegiatan eco-collaboration

c. Eco-Education, pada metode terakhir ini telah dilaksanakan pula sosialisasi secara daring bertema budaya literasi. Program ketiga memiliki tujuan mengedukasi warga khususnya remaja kader dan anak anak dalam menghidupkan dan menggerakkan literasi pasca pandemi sebagai kesiapan dalam hadapi new reallity. Karena dengan literasi maka bentuk kehidupan baru telah mulai terwujud. Kegiatan secara daring telah diwujudkan dan akan dilanjutkan pada pembentukan kader penggerak literasi.
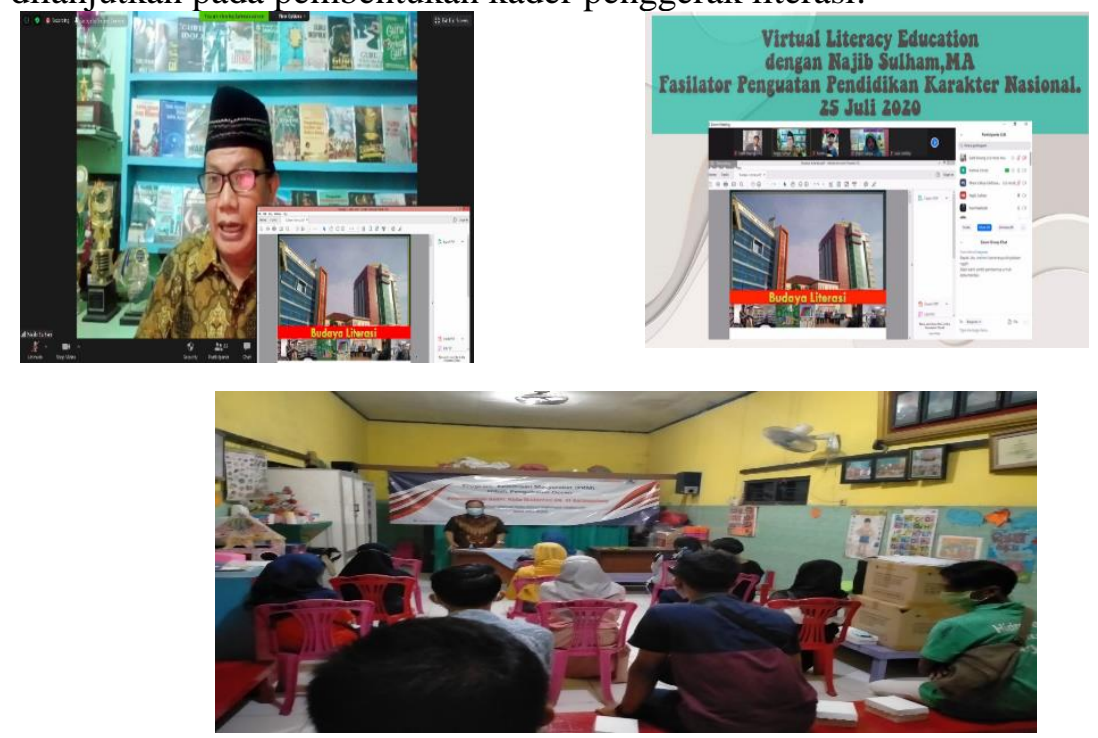

Gambar 7. Foto Kegiatan literasi daring dan pembentukan kader penggerak literasi 
Pada kegiatan tersebut dapat dianggap sebagai salah satu upaya dalam mewujudkan budaya literasi berbasis lingkungan yang lebih dikenal ekoliterasi, tiga metode sebagai tumpuan utama dalam mempertahankan dan diharapkan dapat mewujudkan budaya literasi yang lebih baik.

Hasil kegiatan terukur melalui bentuk respon mitra, sebagai dasar tingkat keberhasilan, bahwa mitra memahami literasi lingkungan dan berupaya dalam mempertahankan dan melestarikan sebagai bentuk kehidupan keseharian yang dapat berguna bagi warga di wilayah stren kali.

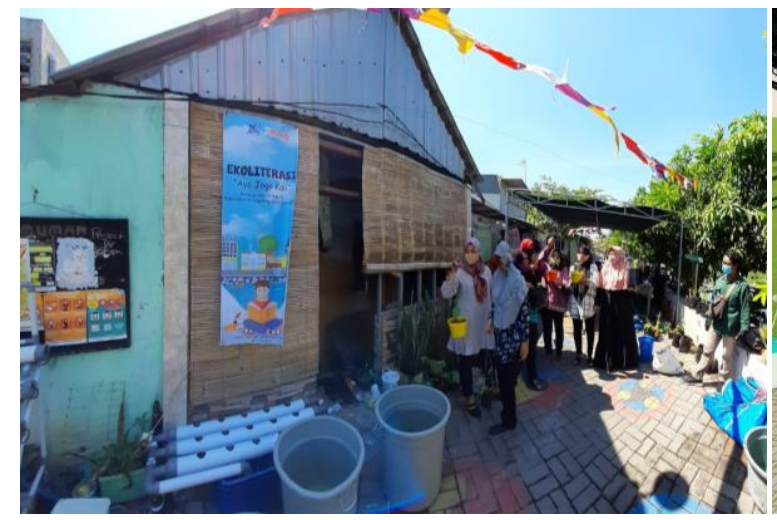

(a)

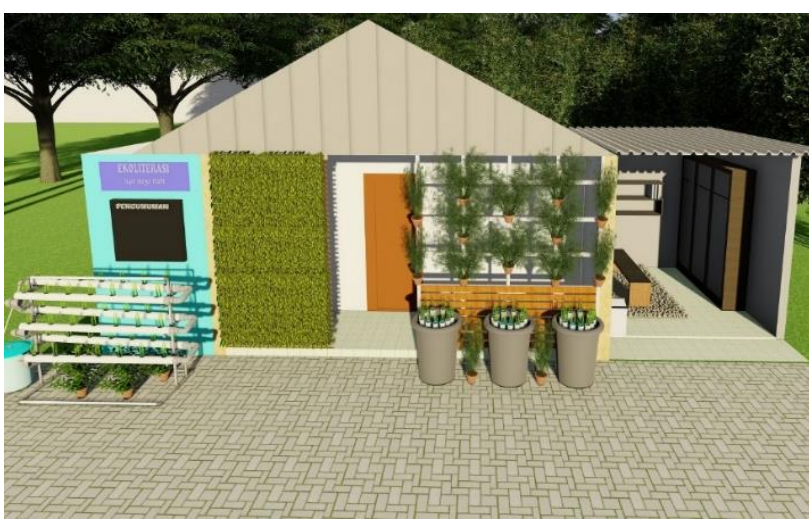

(b)

Gambar 8 (a) keadaan sekarang (b) sketsa rancangan pos ekoliterasi percontohan RT.02 RW.01

Dalam program ini juga masih terkendala beberapa hal dalam pelaksanaannya, antara lain daerah stren kali berada di wilayah RT 2, Rt 6 dan RT 5, namun hanya RT. 2 saja yang bisa aktif dalam kegiatan sebab permasalahan interen kepemimpinan, sehingga berdampak pula dalam pasifnya kegiatan. Masalah lainnya yakni warga kurang maksimal jika mengikuti kegiatan secara daring, sehingga pelaksanaan dilakukan secara luring dan hal ini lebih efektif dan dalam kondisi pandemic masih memperhatikan standar protokol kesehatan sebab zona di wilayah kota Surabaya sampai pada bulan September masih pada wilayah zona orange artinya cukup tinggi. Selain itu keterbatasan anggaran yang berdampak pada program yang belum menyentuh semua warga.

Namun warga sangat mendukung upaya program selanjutnya. Selama praktik pelaksanaan program literasi ditengah warga, untuk mengantisipasi kegiatan yang harus dilaksanakan secara daring, maka warga dipersiapkan agar melek digital, sehingga diadakan workshop penggunaan media digital bagi warga.

Metode 3 ekoliterasi akan lebih dikembangkan lagi sesuai dengan kebutuhan warga di RW. 01. Pengembangan tersebut fokus pada luaran capaian seperti buku panduan ekoliterasi untuk warga, menambah koleksi buku-buku dan membuat perpustakaan mini bertema lingkungan di rumah percontohan literasi, serta menggerakkan RW untuk budidaya ikan dan tanaman dalam ember setidaknya 1 (satu) rumah satu budidamber. Pada Gambar 8 dapat dilihat sketsa rancangan pos ekoliterasi percontohan untuk RT. 02 RW.01.

\section{SIMPULAN}

Dengan jargon kegiatan ayo jogo kali, kegiatan ekoliterasi atau melek lingkungan telah memberikan pemahaman pada warga khususnya RT.02 RW 01. Kesemuanya itu sebagai bentuk upaya menguatkan warga pasca pandemi serta menyiapkan kondisi new reallity. Kepedulian lingkungan dalam bentuk ekoliterasi adalah wujud kesiapan tersebut. Ketercapaian target yang awalnya hanya memberikan penyuluhan saja, pada akhirnya bertambah dengan adanya kegiatan lain seperi urban farming dan pembentukan penggerak literasi. Terbentuknya kegiatan-kegiatan tersebut didasarkan pada pentingnya gerakan ekoliterasi di tengah masyarakat stren kali. Kegiatan ini akan terus dikembangkan pada masyarakat di bawah pengawasan RW dan penggerak literasi di wilayah tersebut. 


\section{SARAN}

Dalam kegiatan literasi berbasis lingkungan tentunya segala tindakan atau upaya menjaga tidak bisa hanya dilakukan sekali, meskipun tinggat keberhasilan tinggi, namun upaya regenerasi juga harus diperhitungkan, maka pendekatan 3 eco harusnya akan lebih dikembangkan lagi pada bidang lainnya yang sangat dibutuhkan warga seperti ekonomi, social budaya dan bidang pendukung lainnya.

\section{UCAPAN TERIMA KASIH}

Pada kesempatan ini, penulis berterima kasih pada tim dan pihak yang banyak memberikan kerja kerasnya, untuk tim hibah, dosen maupun mahsiswa yang sudah bersusah payah dalam mengupayakan mencapai kegiatan, kemenristekdikti atas kesempatan untuk membuktikan bahwa kegiatan pengabdian merupakan kegiatan yang sangat bermanfaat utnuk masyarakat luas, LPPM dan Universitas Muhammadiyah Surabaya, dan warga RW. 01 Kelurahan Karangpilang Surabaya, khususnya warga di wilayah dekat sungai yang banyak terlibat dan semangatnya dalam kegiatan dengan tetap patuh pada protokol kesehatan saat pandemi Covid-19.

\section{DAFTAR PUSTAKA}

Abidin, Y. (2017). Pembelajaran literasi; meningkatkan kemampuan literasi, matematika, sains, membaca dan menulis. Bandung: Bumi Aksara.

Aminuddin (2013). Menjaga Lingkungan hidup dengan kearifan lokal. Bandung: Buku Kita.com.

Capra, F (1996). The Web of Life: A New Scientific Understanding of Living Systems. New York: Anchor Books.

Capra, F. (2007). Sustainable living, ecological literacy, and the breath of life. Canadian Journal of environmental education, 12, 9-18.

Rahmadi, Deva Kurniawan. 2009. Permukiman Bantaran Sungai: Pendekatan Penataan Kawasan Tepi Air dalam Buletin Tata Ruang edisi ke-5, September - Oktober 2009, Pengembangan Wilayah Pesisir dan Tepi Air. Jakarta: Sekretariat Tim Pelaksana BKPRN.

Setiawan, Rulli. (2010). Penggusuran Permukiman Liar di Stren Kali Jagir: Sebuah Tinjauan dari Sisi Hukum dan Humanisme. 10.13140/RG.2.1.1044.5283.

Soemarwoto (1994). Ekologi, Lingkungan hidup dan pembangunan. Jakarta: Djambatan.

Soenyono (2006). Perkembangan Permukiman di Bantaran Sungai Surabaya dari Perspektif Sosiologi. Jurnal Penelitian Humaniora, 11(2), 85-101. 